\title{
Environmental life cycle assessment of water supply in South Africa: The Rosslyn industrial area as a case study
}

\author{
Landu Landu and Alan C Brent* \\ Chair of Life Cycle Engineering, Department of Engineering and Technology Management, University of Pretoria, South Africa
}

\begin{abstract}
Environmental life cycle assessment (LCA) is an environmental management tool, which is increasingly used for decisionsupport in the South African manufacturing industry, e.g. for cleaner production purposes. The life cycle impact assessment (LCIA) phase of LCAs evaluates the potential environmental impact profiles of industrial activities throughout the life cycles of products and processes. The LCIA procedure is dependent on a comprehensive life cycle inventory (LCI) of the evaluated life cycle system. Water usage is included in LCIs, and is incorporated in LCIA procedures as direct extraction from available resources. However, the environmental burdens associated with water supply extend beyond extraction and include nonrenewable energy use, materials use, land use, and pollution of air, soil and water resources. A LCA study was subsequently undertaken to identify key environmental aspects that should be considered where water is used in the manufacturing sector of South Africa, and to identify possible shortcomings in the LCA tool. It is concluded that the extraction of the required water from nature to supply potable water is in fact the most important consideration, and water-losses in the supply system must receive attention, especially in the municipal-controlled part. Water quality impacts are also important, although through supporting processes, and specifically electricity generation. The boosting requirements attribute most to the electricity dependency of the studied life cycle system. However, a number of data gaps were identified and recommendations are made to improve such future LCA studies in South Africa.
\end{abstract}

Keywords: life cycle assessment, life cycle management, life cycle impact assessment, water supply, water use, South Africa

\section{Introduction}

The ISO 14000 family of standards aims to achieve standardisation in the field of environmental management (ISO, 2003) and is a response to an increasing need to incorporate environmental management systems (EMS) into existing business practices (Tibor and Feldman, 1996). Life cycle assessment (LCA) is included in the ISO 14000 series (ISO 14040) as a tool for environmental management decision support (ISO, 2003).

LCA is a quantitative procedure to assess the environmental burdens associated with the life cycle of an activity (product, process, or service) (IISD, 1996). A complete life cycle (of a product) includes raw material extraction (including water), processing, transportation, manufacturing, distribution, use, reuse, maintenance, recycling, and final waste disposal (Consoli et al., 1993). The main objectives of decision makers to initiate a LCA study are to (Allen et al., 1997):

- Provide a profile (as complete as possible) of the interactions of an activity (product, process or service) with the environment

- Contribute to the understanding of the overall and independent nature of the environmental consequences of human activities

- Provide decision makers with information, which quantifies the potential environmental impacts of activities and identifies opportunities for environmental improvements.

* To whom all correspondence should be addressed.

용 +27 12420 3929; fax: +27 12362 5307;

e-mail: alan.brent@up.ac.za

Received 19 August 2005; accepted in revised form 6 December 2005.

\section{Identified research problem and rationale}

International LCA literature indicates that few data are available pertaining to potable water production and supply, in particular with respect to the environmental burdens generated within the system. Furthermore, compared to most developed countries where the LCA procedure has been applied on water systems, i.e. Europe (Raluy et al., 2005), the total environmental burdens associated with potable water supply are ill understood in the South African context due to dissimilar infrastructure that are associated with the limited water supply. In addition to the environmental impacts that are directly related to the infrastructure, e.g. water losses, the data of the auxiliary processes to the infrastructure are also deficient in South Africa, e.g. process-specific data of electricity generation and supply, waste management, etc. Consequently, the inaccessibility to sufficient life cycle inventory (LCI) databases for South African LCA practitioners and researchers has been noted (Brent et al., 2002). Particularly, the LCIs of the three operational parameters that are usually measured in the South African manufacturing industry for cleaner production purposes (Brent and Visser, 2005), must be developed further: water usage, energy usage, and waste produced per manufactured or supplied item.

\section{Objectives of this research}

In general the project summarised in this paper (Brent and Landu, 2005) aimed to study the environmental life cycles of potable water supply systems for industrial usage in South Africa. Thereby, the following could be achieved: 


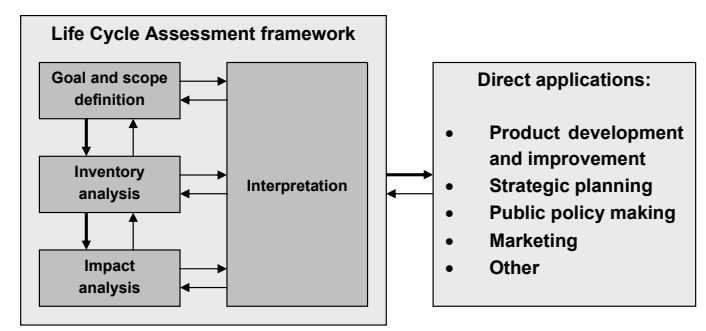

Figure 1

Standardised phases of the LCA procedure (SABS, 1998)

- The existing LCI databases in South Africa could be developed and expanded, which address the needs of local LCA practitioners and researchers

- Environmental improvements of potable water supply systems could be identified

- The benefits of conducting LCAs as an environmental management tool could be demonstrated for the South African manufacturing industry.

The study subsequently compiled detailed LCI data of the supply of potable water, which include all constituents that interact between the technosphere and nature, i.e. extraction of resources and emissions to resources, and then conducted a life cycle impact assessment (LCIA) of the compiled LCI in order to ascertain the overall potential environmental burdens associated with the supply of potable water.

Based on the abovementioned study, the specific objectives of this paper are to:

- Identify key environmental aspects that should be considered where water is used in the manufacturing sector of South Africa

- Identify possible shortcomings (for further research) in the LCA tool and associated methodologies when it is applied for (water-related) decision-support in the South African manufacturing industry.

\section{Research methodology}

A case study was used as basis to realise the general aims of the research, i.e. the supply of potable water to the Rosslyn industrial zone north of Pretoria in the Tshwane metropolitan area. The reason for choosing the Rosslyn industrial zone was that the automotive manufacturing industry had been rapidly expanding there (Venter, 2004), and the environmental impacts coupled to water usage had been questioned in this industry sector (Brent and Visser, 2005).

The study closely followed the four phases (see Fig. 1) as stipulated in the international standard for conducting LCAs (ISO 14040) (SABS, 1998), which have been described in detail elsewhere (Neitzel, 1996; Guinée et al., 2001):

- Goal and scope definition, which describes the application or specific interest, and indicates the target group. A detailed description of the system to be studied is included, providing a clear delimitation of scope, periods and system boundaries.

- LCI analysis, which quantifies the environmentally relevant inputs and outputs of the studied system, which is essentially a mass and energy balance of each unit, or smaller, process within the larger system. ISO has provided a general framework for the inventory analysis (ISO 14041).

- LCIA, which quantifies the environmental impact potential of the inventory data.

- Life cycle assessment and interpretation (LCAI) and improvement analysis, whereby options are identified and evaluated to reduce the environmental impacts of the studied system.

The four phases of the LCA study are described in detail in Brent and Landu, 2005.

\section{The water supply life cycle system case study}

The life cycle system that was studied is the supply of potable water to the Rosslyn industrial zone by Rand Water (2004) and the Tshwane Municipality. The main unit processes that are included in the supply system are summarised in the schematic diagram of Fig. 2.

Untreated water from the Vaal River enters the water works at the Zuikerbosch purification facilities and primary pumping stations. The sludge generated in the purification of raw water at the Zuikerbosch facility is treated at the Panfontein sludge disposal site. The treated water is then boosted to secondary pumping stations. With respect to the treated water that is finally supplied to the Rosslyn industrial zone, this is the Palmiet booster at an altitude of roughly $1435 \mathrm{~m}$ a.m.s.l. and approximately $46 \mathrm{~km}$ from Zuikerbosch. The potable water is then pumped through pipelines to the Klipriviersberg group of reservoirs and storage tanks at the highest level of $1795 \mathrm{~m}$ a.m.s.l. At the reservoirs the pressure is broken and water is gravitated, i.e. no power is used, to Rosslyn, which consumes in the region of $7 \mathrm{Ml} / \mathrm{d}$ at an elevation of $1260 \mathrm{~m}$ a.m.s.1.

The LCA study considered the supply of potable water with typical operations on an annual basis of the Rand Water network in the Gauteng Province only. As far as was possible, all the LCI data were related to 2002 figures. The input and output inventory of the life cycle system, including monthly consumption of land, water, energy and materials, as well as soil, water and air emissions, were derived from on-site investigations at 
the present (2003 to 2004) Rand Water facilities. The data were therefore collected during technical visits to several selected plants (Panfontein, Zuikerbosch, etc.) and from annual reports. With respect to data pertaining to the reservoirs, the Tshwane Municipality's database was used. Other necessary data were gathered from international literature where direct data were not obtainable or transparent and calculated to the daily statistics (e.g. losses through leaks or evaporation) of the actual production and supply system of potable water.

In addition to the main and sub-unit processes that are required in the direct value chain of the supplied water, auxiliary processes are required. These are, but not limited to, the following:

- Energy inputs, in the form of electricity and fuel, which must be generated or produced separately with associated environmental impacts, and raw energy materials, e.g. coal, that are required for boilers, etc.

- The manufacturing of chemical materials that are required in the life cycle system, e.g. chlorine gas for the chlorination phase of the purification step

- Specific energy and material requirements during abnormal operations, e.g. when maintenance on any unit process is required

- Construction material for the capital equipment in the life cycle system

- Transportation within or between unit processes, e.g. rail or road transport of required materials, piping of the supplied water, etc.

Therefore, by considering all of the important unit processes, the overall environmental burdens coupled to the life cycle system may be calculated. For this LCA study (Brent and Landu, 2005) the relative mass energy economic (RMEE) method was used to determine which unit processes should (initially) be included in the boundaries of the studied life cycle system (Raynolds et al., 2000a; Raynolds et al., 2000b). Following typical LCA approaches (Raluy et al., 2005) a functional unit of $1 \mathrm{Ml} / \mathrm{d}$ of potable water supplied at Rosslyn at the quality stipulated in Rand Water guidelines and suitable for industrial use, e.g. in a brewery, was used to which all results are reported.

\section{The limitations of this LCA case study}

The limitations of the LCA case study are specifically noted as follows:

- The study focused on the Rand Water network only, and it may therefore be problematic to relate the results to other water supply systems in South Africa

- Confidentiality issues limited the availability of certain site-specific data, or reduced the accuracy of the data with respect to true environmental performances of the different industrial processes. In terms of the latter, there is a general reluctance by South African companies to provide input data for LCA studies (Friedrich and Buckley, 2002). The LCI data of the electricity generation and fuel production processes, especially, are limited to the South African context. Similarly, information about chemicals that are used in water supply systems was not easily obtainable from the manufacturers due to technical and internal reasons. Where data from literature were used, it was assumed that similar processes are used in the production and supply system of potable water.

- The collection of data is the most time-consuming part in an LCA and involves a great deal to obtain transparent and representative information about the many processes in a production system (Jimenez-Gonzales et al., 2000). Consequently, time-constraints reduce the completeness of the LCI data.

\section{Further data gaps and assumptions}

It is believed that gaps and omissions in the inventory data in LCAs are inevitable to some degree now and in the future. LCAs cannot cover all issues or every part of complex industrial systems and, therefore, LCAs will always be incomplete in some way (Owens, 1999). The following data gaps in the LCI are noted:

- Eskom (2005) generates the electricity that is consumed for the production and supply system of potable water. Data on the electricity production lacked information, such as trace elements emitted when burning coal and the complete list of inputs in the production of electricity.

- There were no exact data on the land usage within the Tshwane reservoir system.

- Data on the output flows of potable water from the Tshwane reservoir system were not available and estimation through calculation had to be used. This aspect poses major problems on water loss calculations. For the life cycle system, it was assumed that the difference between the raw water inflow and supplied water outflow is lost through either emissions (leaks) or accidental releases such as spills.

- Chemical inputs for water purification were estimated and included in the inventory with data gaps on the amount of chlorine used at the booster stations.

- Emissions to water and air at the booster stations had to be estimated because of the lack of information.

The following assumptions were further made with respect to the LCI and the goal and scope definition phase:

- It was assumed that the Rand Water network supplies all of the water that is consumed in the Rosslyn industrial zone, i.e. only the routes that lead to the Rosslyn industrial area were accountable in the inventory study.

- The potable water pumped to Palmiet is blended with Zuikerbosch and Vereeniging. In this study, it was assumed that Zuikerbosch plays a major role in this process, i.e. raw water from Vaal Dam is processed at Zuikerbosch only; and input and output flows of the Vereeniging purification and pumping station were subsequently not accounted for in this study.

- The input and output flows of the raw water extraction unit process were assumed to be of minor impact in the current study.

- Panfontein's core business is the disposal of water works sludge produced as a by-product of the water purification process at Rand Water's Vereeniging and Zuikerbosch pumping stations. However, it was assumed that Panfontein receives water works sludge from Zuikerbosch pumping station only because Vereeniging is not part of the network system considered in this study.

- The disposal site on the Panfontein premises can be described as a general landfill site.

- For the energy consumption at Zuikerbosch plants, $6 \%$ is assigned to ZKB1, $12 \%$ to ZKB2, 35.6\% to ZKB3, $44.8 \%$ to ZKB4\&4b. It was assumed that every input at this life cycle stage can be multiplied according to this percentage.

- Any transportation requirements, e.g. for the supply of chemicals, occur via road (40 $t$ trucks) and the suppliers are within a $50 \mathrm{~km}$ range of the applicable unit process. 


\begin{tabular}{|c|c|c|c|c|c|}
\hline \multicolumn{6}{|c|}{$\begin{array}{r}\text { TABLE } 1 \\
\text { Overall inventory for life cycle system in }\end{array}$} \\
\hline & & Constituent & Value & Unit & Comment \\
\hline \multirow{2}{*}{ 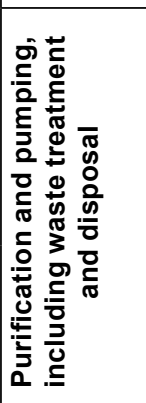 } & 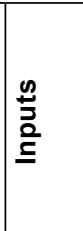 & $\begin{array}{l}\text { Raw water } \\
\text { Recovered water } \\
\text { Chemicals } \\
\text { Electricity } \\
\text { Land use } \\
\text { Fuel }\end{array}$ & $\begin{array}{l}1.292 \\
0.019 \\
0.209 \\
937.3 \\
5466 \\
0.389\end{array}$ & $\begin{array}{l}\text { M } \\
\text { M } \ell \\
\mathrm{t} \\
\mathrm{MJ} \\
\mathrm{m}^{2} \cdot \mathrm{a} \\
\ell\end{array}$ & $\begin{array}{l}\text { Obtained from Vaal River } \\
\text { Obtained from Panfontein } \\
\text { See Table } 7 \text { of Brent and Landu, 2005 } \\
\text { See Appendix A of Brent and Landu, } 2005 \\
\text { See Appendix A of Brent and Landu, } 2005 \\
\text { See Appendix A of Brent and Landu, } 2005\end{array}$ \\
\hline & 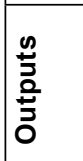 & $\begin{array}{l}\text { Treated and pumped water } \\
\text { Solid/liquid waste } \\
\text { Emergency discharges } \\
\text { Dust fall-out }\end{array}$ & $\begin{array}{l}1.283 \\
0.021 \\
0.027 \\
0.667\end{array}$ & $\begin{array}{l}\text { M } \ell \\
\text { M } \\
\text { M } \ell \\
\mathrm{g}\end{array}$ & $\begin{array}{l}\text { Pumped up to the booster stations } \\
\text { Sent to Panfontein landfill site } \\
\text { Emergency discharge into water sources } \\
\text { See Appendix A of Brent and Landu, } 2005\end{array}$ \\
\hline \multirow{2}{*}{ 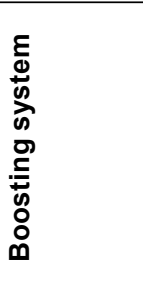 } & 量 & $\begin{array}{l}\text { Potable water received } \\
\text { Chemicals used } \\
\text { Electricity } \\
\text { Fuel } \\
\text { Land use }\end{array}$ & $\begin{array}{l}1.270 \\
0.005 \\
2923 \\
0.478 \\
12.76\end{array}$ & $\begin{array}{l}\mathrm{M} \ell \\
\mathrm{t} \\
\mathrm{MJ} \\
\ell \\
\mathrm{m}^{2}\end{array}$ & $\begin{array}{l}\text { See Fig. } 3 \\
\text { See Table } 7 \text { of Brent and Landu, } 2005 \\
\text { See Appendix A of Brent and Landu, } 2005 \\
\text { See Appendix A of Brent and Landu, } 2005 \\
\text { See Appendix A of Brent and Landu, } 2005\end{array}$ \\
\hline & 站 是 & $\begin{array}{l}\text { Potable water pumped } \\
\text { Dust fall-out }\end{array}$ & $\begin{array}{l}1.265 \\
0.025\end{array}$ & $\begin{array}{l}\mathrm{M} \ell / \mathrm{d} \\
\mathrm{g}\end{array}$ & $\begin{array}{l}\text { See Fig. } 3 \text { - pumped up to reservoirs } \\
\text { See Appendix A of Brent and Landu, } 2005\end{array}$ \\
\hline \multirow{2}{*}{ 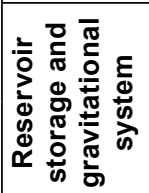 } & $\doteq \stackrel{\infty}{\Xi}$ & $\begin{array}{l}\text { Received potable water } \\
\text { Land use }\end{array}$ & $\begin{array}{l}1.250 \\
178.1\end{array}$ & $\begin{array}{l}\mathrm{M} \ell / \mathrm{d} \\
\mathrm{m}^{2}\end{array}$ & $\begin{array}{l}\text { See Fig. } 3 \\
\text { See Appendix A of Brent and Landu, } 2005\end{array}$ \\
\hline & ठ̀ & Supplied potable water & 1.0 & $\mathrm{M} \ell / \mathrm{d}$ & $\begin{array}{l}\text { Supplied directly to Rosslyn industrial } \\
\text { area in the Tshwane municipal district }\end{array}$ \\
\hline
\end{tabular}

\section{Relating data and data aggregation}

The quantitative input and output data that were obtained for the different unit processes were converted according to the functional unit of the overall life cycle system, i.e. $1 \mathrm{Ml} / \mathrm{d}$ of potable water. For example, the $\mathrm{CO}_{2}$ emissions released by the electricity generation and supply unit processes are reported per MJ of electricity supplied. Thereafter, with relation to the functional unit, the amount of $\mathrm{CO}_{2}$ emissions associated with electricity is reported per $\mathrm{Ml} / \mathrm{d}$ of potable water supplied to the Rosslyn industrial area.

Data aggregation leads to the presentation of the inventory table, which is the collection of values for all input and outputs for all unit processes involved in a system (Friedrich and Buckley, 2002). For this LCI, the overall inventory table consists of three main parts (see Table 1):

- Water purification and pumping, including the waste treatment and disposal stage

- Boosting system

- Reservoir storage and gravitational system.

The quantitative inputs and outputs of the electricity generation and supply are not reported separately in the overall inventory table. As the electricity unit process is included in the system boundaries of the LCI, these inputs and outputs can be obtained form the electricity required (as shown in Table 1) and through a linear manipulation of the data in the detailed report by Brent and Landu, 2005. The water losses that occur along the supply system, and which translate to the inflow and outflow values of Table 1, are summarised in Fig. 3.

Sensitivity analyses were applied in the interpretation phase of the LCA to evaluate the uncertainty of the LCI data and to determine how changes in key parameters influence the LCIA results (Crettaz et al., 1999). The completeness and con-

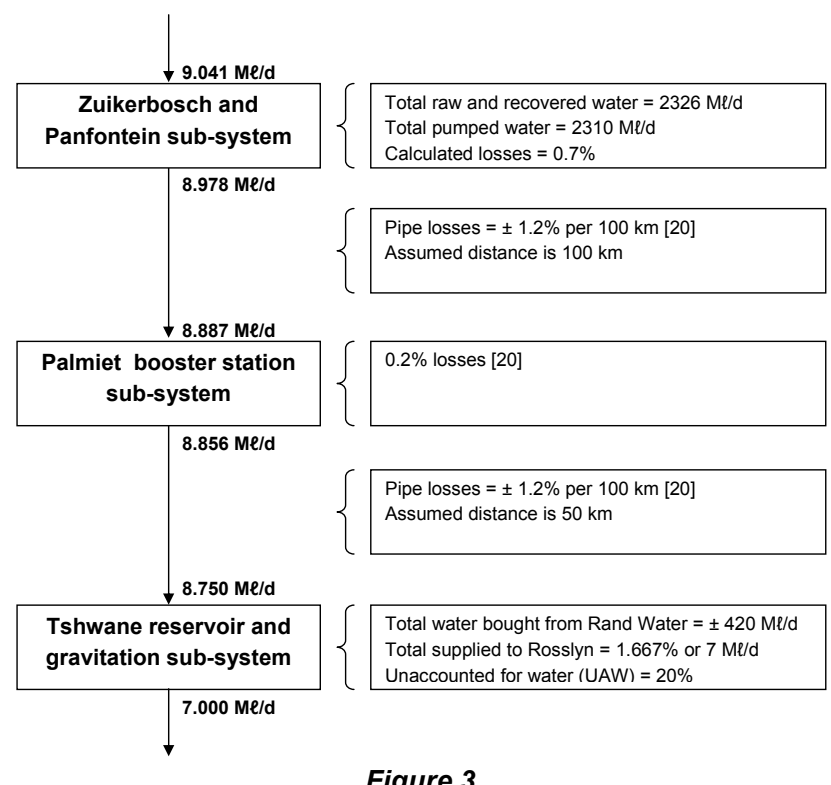

Figure 3

Water loss assumptions and calculated values

sistencies of the LCI data were also established. These interpretation analyses (LCAI) are described in detail in Brent and Landu, 2005.

\section{Results: Environmental LCIA}

\section{The LCIA methodology that was applied}

An LCIA methodology that was developed for South Africa (Brent, 2003; Brent, 2004; Brent and Visser, 2005) was applied in the LCA study. The RII calculation procedure of the LCIA methodology is described in detail elsewhere (Brent, 2003; 


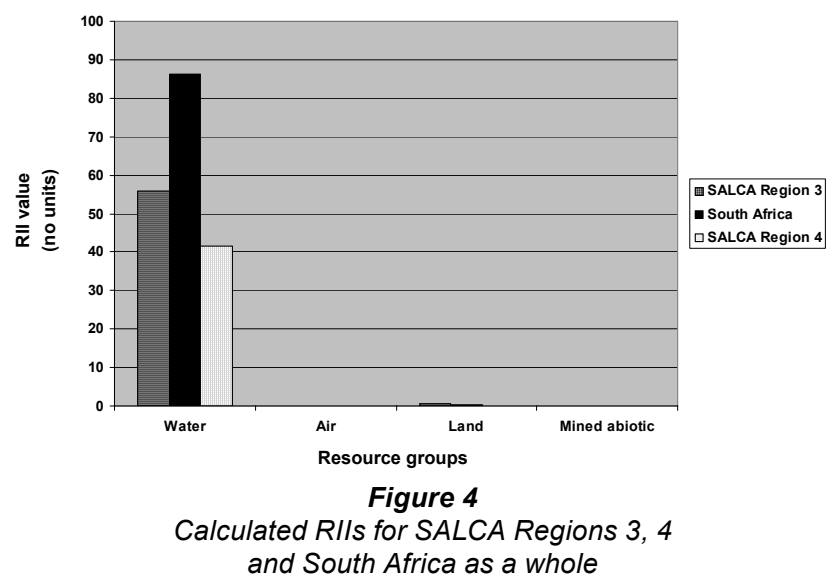

Brent, 2004), but in essence a distance-to-target approach is used for the normalisation of midpoint environmental impact categories, which focuses on the ambient quality and quantity objectives for four resource groups: air, water, land and mined abiotic resources. The quality and quantity objectives are determined for defined South African Life Cycle Assessment (SALCA) Regions and take into account endpoint or damage targets. Following the precautionary approach, a resource impact indicator (RII) is calculated for the resource groups.

The calculation of a RII for the water use (WU) impact category is used as an example. The entire life cycle system, including auxiliaries, extracts $1.294 \mathrm{M} \ell$ of water from various natural sources per functional unit. All of the LCI constituents that contribute to this impact category are converted to a singular unit of equivalence, i.e. $\mathrm{kg}$ of water reserves, by multiplying each constituent value with an appropriate characterisation value. A value of $1 \mathrm{~kg} / \ell$ is used for all water use LCI constituents, and the total characterised result for the WU impact category is therefore $1.294 \times 10^{6} \mathrm{~kg}$ of water reserves.
The characterised result is then normalised, to compare its significance with other RIIs, using current and target water quantities that were determined from available and projected annual water balances, which are based on maximum surface and groundwater yields, human and ecosystem consumption, and the transfer of water reserves from other catchments (inside and outside South Africa), in the stipulated SALCA Regions (DEAT, 2000; Basson et al., 1997), and corrected for the population in that region. In the case of SALCA Region 4 the current (1996) value was $2562 \times 10^{6} t$ and the projected target value (2030) $550 \times 10^{6} \mathrm{t}$, with a population of just over 3 million (in 1996). The final RII value is then calculated by dividing the characterisation result with the target value per person (normalisation) and then multiplying the result with a significance factor, i.e. current value divided by the target value, which is a value of 33.5. By adding the RII value for the WU impact category to the RII values for the other waterrelated impact categories, an overall RII value can be determined for the impact of the entire life cycle system on water resources per functional unit.

\section{LCIA profile analyses}

The LCIA results, when applying the Resource Impact Indicator (RII) method to the baseline LCI 'snapshot' (see Appendix $\mathbf{C}$ of Brent and Landu, 2005) are summarised in Fig. 4 and Table 2. The LCIA results are reported for SALCA Region 4, where the water is extracted and most of the main unit processes are located; SALCA Region 3, where the Rosslyn industrial area is located; and for South Africa as a whole. The normalised environmental profiles for each of the main resource groups are shown separately in Figs. 5 to 8. Furthermore, contribution analyses results are summarised in Table 3 in terms of:

- The most important impact categories in terms of contributions (of more than $1 \%$ ) to the calculated RII values for the

\begin{tabular}{|c|c|c|c|c|c|}
\hline \multicolumn{6}{|c|}{$\begin{array}{c}\text { TABLE } 2 \\
\text { LCIA results for the baseline } \mathrm{LCI} \text { snapshot }\end{array}$} \\
\hline Resource group & \begin{tabular}{|l|} 
Impact \\
category
\end{tabular} & \begin{tabular}{|l|}
$\begin{array}{l}\text { Characterisation } \\
\text { value }\end{array}$ \\
\end{tabular} & Unit $^{\mathrm{b}}$ & \begin{tabular}{|l|}
$\begin{array}{l}\text { Normalisation } \\
\text { (SALCA Region 4) }\end{array}$ \\
\end{tabular} & $\begin{array}{l}\text { Normalisation } \\
\text { (South Africa) } \\
\end{array}$ \\
\hline \multirow[t]{5}{*}{ Water resources } & WU & $1.294 \times 10^{6}$ & kg water reserves & $3.346 \times 10^{1}$ & $8.424 \times 10^{1}$ \\
\hline & EP & $2.726 \times 10^{-1}$ & $\mathrm{~kg} \mathrm{PO}_{4}^{3-}$ eq. & $3.103 \times 10^{-5}$ & $4.492 \times 10^{-6}$ \\
\hline & AP & $9.810 \times 10^{1}$ & $\mathrm{~kg} \mathrm{H}_{2} \mathrm{SO}_{4}$ eq. & $1.581 \times 10^{-3}$ & $6.130 \times 10^{-4}$ \\
\hline & \begin{tabular}{|l|} 
HTP \\
\end{tabular} & $7.523 \times 10^{1}$ & kg Pb eq. & $7.954 \times 10^{0}$ & $2.005 \times 10^{0}$ \\
\hline & ATP & $1.714 \times 10^{-1}$ & kg $\mathrm{Pb}$ eq. & $1.812 \times 10^{-2}$ & $4.567 \times 10^{-3}$ \\
\hline \multirow[t]{5}{*}{ Air resources } & AP & $5.997 \times 10^{0}$ & $\mathrm{~kg} \mathrm{SO}_{2}$ eq. & $1.263 \times 10^{-2}$ & $3.267 \times 10^{-3}$ \\
\hline & OCP & $2.285 \times 10^{-1}$ & $\mathrm{~kg} \mathrm{O}_{3}$ eq. & $3.657 \times 10^{-5}$ & $9.182 \times 10^{-6}$ \\
\hline & ODP & $4.570 \times 10^{-6}$ & kg CFC-11 eq. & $1.203 \times 10^{-12}$ & $5.762 \times 10^{-13}$ \\
\hline & GWP & $9.105 \times 10^{2}$ & $\mathrm{~kg} \mathrm{CO}_{2}$ eq. & $2.298 \times 10^{-10}$ & $1.100 \times 10^{10}$ \\
\hline & HTP & $1.984 \times 10^{0}$ & $\mathrm{~kg} \mathrm{~Pb}$ eq. & $3.898 \times 10^{-4}$ & $1.033 \times 10^{-4}$ \\
\hline \multirow[t]{5}{*}{ Land resources } & AP & $9.810 \times 10^{1}$ & $\mathrm{~kg} \mathrm{H}_{2} \mathrm{SO}_{4}$ eq. & $1.581 \times 10^{-3}$ & $6.130 \times 10^{-4}$ \\
\hline & \begin{tabular}{|l|} 
HTP \\
\end{tabular} & $2.805 \times 10^{-1}$ & kg Pb eq. & $1.329 \times 10^{-7}$ & $6.360 \times 10^{-8}$ \\
\hline & TTP & $7.566 \times 10^{-2}$ & kg $\mathrm{Pb}$ eq. & $3.584 \times 10^{-8}$ & $1.716 \times 10^{-8}$ \\
\hline & OLU & $4.463 \times 10^{3}$ & $\mathrm{~m}^{2}$.a near natural & $2.599 \times 10^{-2}$ & $1.765 \times 10^{-1}$ \\
\hline & TLU & $3.442 \times 10^{0}$ & $\mathrm{~m}^{2}$ non-natural & $1.292 \times 10^{-4}$ & $5.834 \times 10^{-4}$ \\
\hline \multirow{2}{*}{$\begin{array}{l}\text { Mined abiotic } \\
\text { resources }\end{array}$} & MD & $9.26 \times 10^{-8}$ & kg Pt eq. & $5.197 \times 10^{-13}$ & $5.197 \times 10^{-13}$ \\
\hline & ED & $5.469 \times 10^{-1}$ & kg coal eq. & $1.968 \times 10^{-6}$ & $1.968 \times 10^{-6}$ \\
\hline
\end{tabular}

a The definitions of the midpoint impact categories are: WU (water use); EP (eutrophication potential); AP (acidification potential); HTP (human toxicity potential); (aquatic toxicity potential); OCP (ozone creation potential); ODP (ozone depletion potential); GWP (global warming potential); TTP (terrestrial toxicity potential); OLU (occupied land usage); TLU (transformed land usage); MD (mineral depletion); energy depletion).

b Refer to the detailed description of the RII LCIA procedure (Brent, 2003; Brent, 2004). 


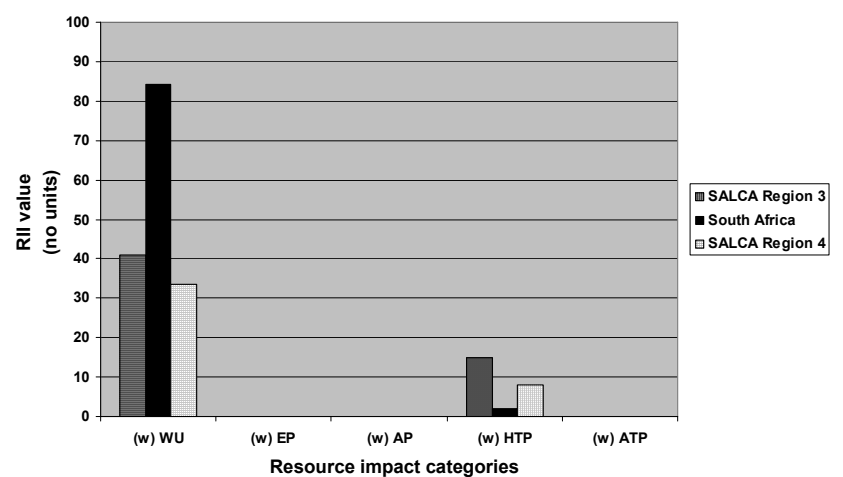

Figure 5

Water RII profile for SALCA Regions 3, 4 and South Africa as a whole

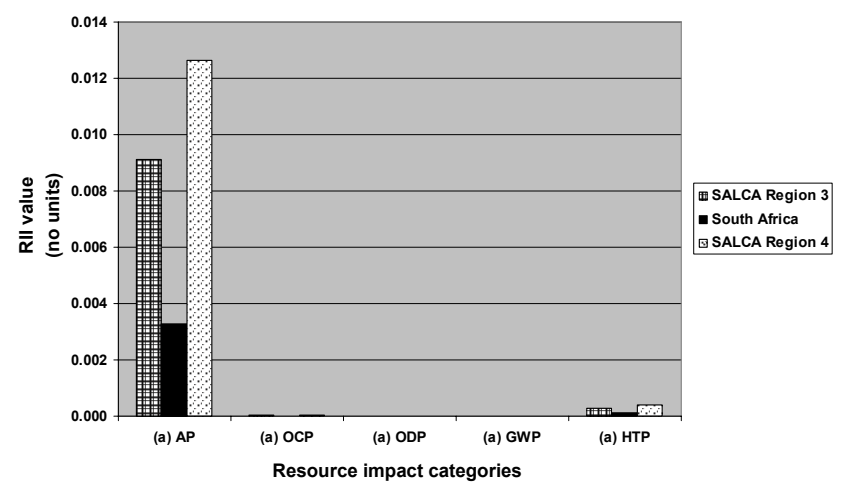

Figure 6

Air RII profile for SALCA Regions 3, 4 and South Africa as a whole

four main resource groups

- The most important inventory flows or constituents in terms of contributions (of more than 1\%) to the respective impact categories

- The associated unit processes, i.e. the unit processes that contribute to more than $99 \%$ of the inventory flow values.

\section{Discussion}

With respect to the overall environmental profile, the impacts on water resources are by far the most important consideration, i.e. the impacts on water resources are at least a factor of 40 compared to the impacts on the other resource groups. However, the total impact on water resources is not only attributable to water extraction. The release of toxic substances by the life cycle system, and specifically the generation of the required electricity for the LCA system, may also be important with respect to the toxicity potential impact categories, i.e. up to $20 \%$ for the SALCA Region 4.

Depending on the water availability in the specific analysed region, water extraction is accountable for at least two-thirds of the total impact on water resources, for SALCA Region 3, and at least three-quarters for SALCA Region 4. It must be noted that considerable water losses of more than $20 \%$ is associated with the baseline LCI. However, by even removing all of these losses, the impact on the available quantity of water resources would still be more than double that of water quality impacts, if SALCA Region 4 is taken as the reference ambient environment, and can be as much as twenty-five times as important as the water quality impacts if the whole of South Africa is taken as reference region.

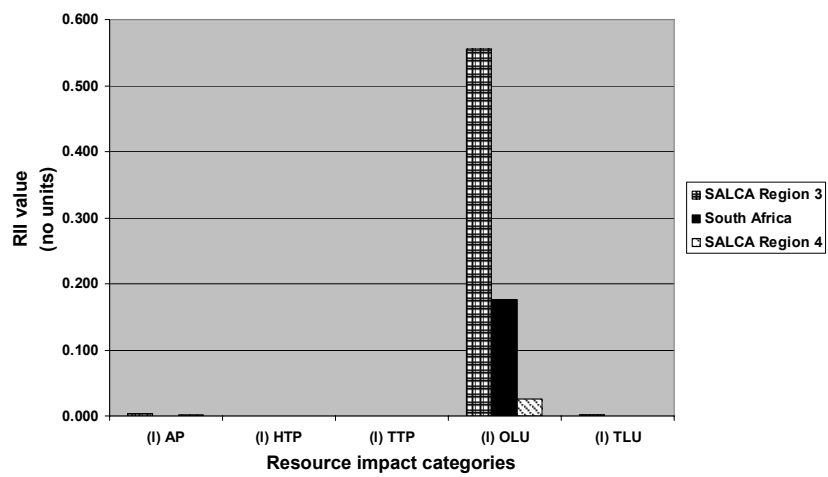

Figure 7

Land RII profile for SALCA Regions 3, 4 and South Africa as a whole

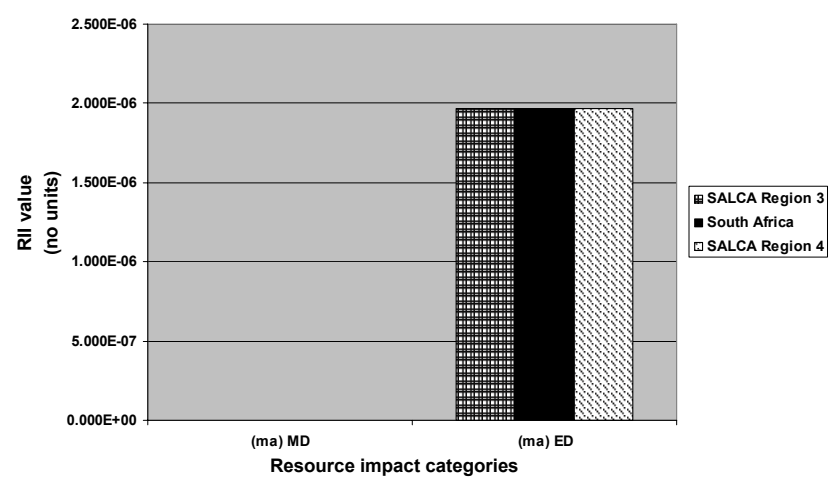

Figure 8

Mined abiotic RII profile for SALCA Regions 3, 4 and South Africa as a whole

After water resources the impacts on land resources are the most important for the life cycle system. However, the impact on land resources is at least four times lower than the impacts on water quality. Of all the impact categories classified to land resources, the occupation of land, directly by the water purification and waste treatment, boosting and reservoirs supply system, is the main contribution to this impact category.

In general the impacts on air resources are the third-most important, although the acidification potential (for air) may be in the same order of magnitude compared to land usage if SALCA Region 4 is used as reference region. The releases of atmospheric emissions that contribute to the acidification potential impact category, due the generation of the required electricity, contribute the most to the impacts on air resources, i.e. at least $97 \%$. Similar to water resources the release of certain substances may also be of importance from a toxicity potential perspective.

The impacts of the water supply system on the depletion of non-renewable minerals and energy are considered insignificant.

\section{Conclusions and recommendations}

The environmental burdens associated with water supply extend beyond extraction from nature and include non-renewable energy use, materials use, land use, and pollution of air, soil, and water resources. This LCA study, based on the standardised ISO 14040 methodology, was consequently undertaken to assess the environmental burdens associated with water supply to an industrial area. The study compiled a comprehensive LCI 
TABLE 3

Contribution analyses of the RII profiles for the entire life cycle system per functional unit

\begin{tabular}{|c|c|c|c|c|c|c|}
\hline RII group & $\begin{array}{l}\text { Impact } \\
\text { category }\end{array}$ & $\begin{array}{l}\% \text { contribution } \\
\text { to RII group }\end{array}$ & $\mathrm{LCl}$ constituent & $\begin{array}{l}\% \text { contribution } \\
\text { to impact } \\
\text { category }^{b}\end{array}$ & $\begin{array}{l}\text { Unit process in } \\
\text { LCA system }\end{array}$ & $\begin{array}{l}\% \text { contribution } \\
\text { to } \mathrm{LCl} \\
\text { constituent }\end{array}$ \\
\hline \multirow[t]{2}{*}{ Water } & WU & $\begin{array}{l}80.75 \\
(97.67) \\
\end{array}$ & Water: River & 99.83 & Water extraction & 100.00 \\
\hline & HTP & $\begin{array}{l}19.20 \\
(2.33)\end{array}$ & $\begin{array}{l}\text { Arsenic (a) } \\
\text { Benzene (a) } \\
\text { Chromium (a) } \\
\text { HF (a) } \\
\text { Lead (s) }\end{array}$ & \begin{tabular}{|l|}
6.72 \\
1.35 \\
79.74 \\
4.87 \\
2.99 \\
\end{tabular} & $\begin{array}{l}\text { Electricity } \\
\text { Electricity } \\
\text { Electricity } \\
\text { Electricity } \\
\mathrm{FeCl}_{3} \\
\mathrm{PAA}^{3} \\
\end{array}$ & $\begin{array}{l}99.99 \\
99.90 \\
99.98 \\
99.93 \\
97.41 \\
2.36 \\
\end{array}$ \\
\hline \multirow[t]{2}{*}{ Air } & AP & $\begin{array}{l}96.73 \\
(96.67)\end{array}$ & $\begin{array}{l}\mathrm{HCl}(\mathrm{a}) \\
\mathrm{NO}_{x} \text { as } \mathrm{NO}_{2}(\mathrm{a}) \\
\mathrm{SO}_{\mathrm{x}} \text { as } \mathrm{SO}_{2}(\mathrm{a})\end{array}$ & $\begin{array}{l}6.41 \\
24.03 \\
68.70 \\
\end{array}$ & $\begin{array}{l}\text { Electricity } \\
\text { Electricity } \\
\text { Electricity } \\
\end{array}$ & $\begin{array}{l}99.93 \\
97.37 \\
97.89 \\
\end{array}$ \\
\hline & HTP & $\begin{array}{l}2.99 \\
(3.06)\end{array}$ & $\begin{array}{l}\text { Arsenic (a) } \\
\text { Benzene (a) } \\
\text { Chromium (a) } \\
\text { HF (a) } \\
\text { Lead (s) }\end{array}$ & $\begin{array}{l}6.69 \\
1.34 \\
79.53 \\
4.84 \\
2.97\end{array}$ & $\begin{array}{l}\text { Electricity } \\
\text { Electricity } \\
\text { Electricity } \\
\text { Electricity } \\
\mathrm{FeCl}_{3} \\
\mathrm{PAA}\end{array}$ & $\begin{array}{l}99.98 \\
99.90 \\
99.98 \\
99.93 \\
97.41 \\
2.36 \\
\end{array}$ \\
\hline \multirow[t]{2}{*}{ Land } & OLU & \begin{tabular}{|l|}
93.83 \\
$(99.33)$ \\
\end{tabular} & $\begin{array}{l}\text { Industrialised }^{\mathrm{d}} \\
\text { Urbanised }^{\mathrm{d}}\end{array}$ & $\begin{array}{l}95.57 \\
4.43 \\
\end{array}$ & $\begin{array}{l}\text { Treatment } \\
\text { Reservoirs }\end{array}$ & $\begin{array}{l}99.84 \\
100.00 \\
\end{array}$ \\
\hline & AP & \begin{tabular}{|l}
5.71 \\
$(0.34)$ \\
\end{tabular} & $\begin{array}{l}\mathrm{NO}_{x} \text { as } \mathrm{NO}_{2}(\text { a) } \\
\mathrm{SO}_{x} \text { as } \mathrm{SO}_{2}(\text { a) }\end{array}$ & $\begin{array}{l}2.27 \\
97.05 \\
\end{array}$ & $\begin{array}{l}\text { Electricity } \\
\text { Electricity }\end{array}$ & $\begin{array}{l}97.37 \\
97.89 \\
\end{array}$ \\
\hline $\begin{array}{l}\text { Mined } \\
\text { abiotic }\end{array}$ & ED & $\begin{array}{l}100.00 \\
(100.00)\end{array}$ & $\begin{array}{l}\text { Coal } \\
\text { Natural gas } \\
\text { Oil }\end{array}$ & $\begin{array}{l}97.49 \\
1.35 \\
\\
1.16\end{array}$ & $\begin{array}{l}\text { Electricity } \\
\text { Electricity } \\
\text { Ammonia } \\
\text { Chlorine } \\
\text { Electricity } \\
\text { Ammonia } \\
\text { Fuel } \\
\text { Chlorine } \\
\text { Diesel }\end{array}$ & $\begin{array}{l}99.80 \\
74.78 \\
20.94 \\
1.20 \\
37.50 \\
27.87 \\
28.14 \\
5.09 \\
1.38 \\
\end{array}$ \\
\hline
\end{tabular}

a Only impact categories that contribute more than $1 \%$ to the respective resource groups are shown in the table; values without parentheses are normalised with SALCA Region 4 factors and values with parentheses are normalised with South African factors.

b Only LCI constituents that contribute more than $1 \%$ to the respect impact categories are shown.

c Only unit processes in the LCA system that contribute more than $1 \%$ to the respective LCI constituents are shown.

d Land occupied as existing extremely industrialised or urbanised land (Brent, 2003; Brent, 2004).

e Includes water purification, treatment and waste disposal.

of water supply to a specific industrial area, i.e. Rosslyn, north of Pretoria in the City of Tshwane. An introduced LCIA framework for South Africa was used to determine the extent of different environmental impacts.

Based on the interpretation of the LCIA (Brent and Landu, 2005 ) it is concluded that the actual extraction of the water from the ambient environment is in fact the most important consideration. The toxicity potential impacts on water resources, mainly due to the required electricity for the water supply system, are of secondary importance. However, the extent of the impact due to water extraction is not accurately reported in the water use category of the LCIA profile, due to the lack of appropriate categorisation factors. For example, ambient water quality may be influenced by the reduction of water quantities. Similarly, the uncertainty of the applied LCIA method and the resultant indicator profile was not included in the interpretation of the LCA study and is assumed to reflect a worst-case scenario as reported in literature (Ross et al., 2002).

The impacts of the required chemicals of the water supply system, i.e. ammonia, chlorine, ferric chloride, polyacrylamide, etc. are of low importance. Also, the required non-renewable energy resources to pump the water from the Vaal River to the reservoir system of the Tshwane metropolitan area are of minor importance.

From these outcomes the following main LCA recommendations are made:

- In order to improve the environmental performance of the water supply system, water-losses must be addressed foremost. Especially within the management domain of the municipality, data are not monitored and recorded to identify the current large problematic areas. The electricity usage is also of importance, albeit to a lesser extent, and it is the boosting stage where this energy input is primarily required. Therefore, more efficient, or possible alternative energy sources may be considered for this part of the life cycle system.

- The LCIA method must be developed further for South Africa, especially in terms of impacts on water resources. In this respect characterisation factors should be developed and/or adapted for South Africa, e.g. for water usage, acidi- 
fication potential, toxicity potential and salinisation potential categories (Leske and Buckley, 2004a; Leske and Buckley, 2004b). Furthermore, normalisation factors for these categories must be established by a larger South African focus group, which represent the different environmental sciences' disciplines, and with international participation.

\section{Acknowledgements}

The authors would like to acknowledge and thank those individuals that participated in the research project and provided valuable inputs, and specifically:

- Tony Muller; Rand Water, Zuikerbosch

- Daniel Nkwadi; Rand Water, Zuikerbosch

- Ilze Badenhorst; Rand Water (environmental and risk assessment), Zuikerbosch

- Rodger Barry; Rand Water, Palmiet central depot

- Graham Duncan; Rand Water, Panfontein

- Thomas Phethla; Rand Water, Head Office

- John Burger; Tshwane Municipality (bulk water services)

- Darry Cassel; Tshwane Municipality (water consumer audit).

Furthermore, the authors would like to thank the Water Research Commission (WRC) for funding this project and the assigned steering committee members for contributing to the scoping of the research and reviewing the outcomes. Especially the feedback from Meiring du Plessis of the WRC is much appreciated.

\section{References}

BASSON MS, VAN NIEKERK PH and VAN ROOYEN JA (1997) Overview of Water Resources Availability and Utilisation in South Africa. DWAF Report No. P RSA/00/0197. Department of Water Affairs and Forestry, Pretoria.

BRENT AC, ROHWER MB, FRIEDRICH E and VON BLOTTNITZ H (2002) Status of life cycle assessment and engineering research in South Africa. Int. J. Life Cycle Assess. 7 (3) 167-172.

BRENT AC (2003) A proposed lifecycle impact assessment framework for South Africa from available environmental data. S. Afr. J. Sci. $99(3 / 4)$ 115-122.

BRENT AC and HIETKAMP S (2003) Comparative evaluation of life cycle impact assessment methods with a South African case study. Int. J. Life Cycle Assess. 8 (1) 27-38.

BRENT AC (2004) A life cycle impact assessment procedure with resource groups as areas of protection. Int. J. Life Cycle Assess. 9 (3) $172-179$

BRENT AC and VISSER JK (2005) An environmental performance resource impact indicator for life cycle management in the manufacturing industry. J. Cleaner Prod. 13 (6) 557-565.

BRENT AC and LANDU L (2005) Environmental Life Cycle Assessment of Water Use in South Africa: The Rosslyn Industrial Area as a Case Study. WRC Report No. 1552/1/05. Water Research Commission, Pretoria.

CONSOLI FJ, ALLEN DT, BOUSTEAD I, FAVA JA, FRANKLIN W, JENSEN AA, DE OUDE N, PARRISH R, PERRIMAN R POSTLETHWAITE D, QUAY B, SEGUIN J and VIGON B (ed.) (1993) Guidelines for Life-Cycle Assessment: A Code of Practice.
Society of Environmental Toxicology and Chemistry (SETAC), SETAC Press, Brussels.

DEAT (DEPARTMENT OF ENVIRONMENTAL AFFAIRS AND TOURISM) (2000) The National State of the Environment Report. Directorate Environmental Information and Reporting, Pretoria.

ESKOM (2005) Proudly African. Website: http://www.eskom.co.za (accessed on 6 December 2005)

FRIEDRICH E and BUCKLEY C (2002) The Use of Life Cycle Assessment in the Selection of Water Treatment Processes. WRC Report No. 1077/1/02. Water Research Commission, Pretoria.

GUINÉE JB, GORRÉE M, HEIJUNGS R, HUPPES G, KLEIJN R, DE KONING A, VAN OERS L, SLEESWIJK AW, SUH S, DE HAES HAU, DE BRUIJN H, VAN DUIN R and HUIJBREGTS MAJ (2001) Life Cycle Assessment - An Operational Guide to the ISO Standards. Centre for Environmental Studies (CML), Leiden University, Leiden.

IISD (INTERNATIONAL INSTITUTE FOR SUSTAINABLE DEVELOPMENT) (1996) Global Green Standards - ISO 14000 and Sustainable Development. IISD, Winnipeg.

ISO (INTERNATIONAL ORGANIZATION FOR STANDARDIZATION) (2003) ISO 14000. http://www.iso.org/iso/en/iso9000-14000/ iso14000/iso14000index.html (accessed on 6 December 2005).

LESKE T and BUCKLEY C (2004a) Towards the development of a salinity impact category for South African life cycle assessments: Part 2 - A conceptual multimedia environmental fate and effect model. Water SA 30 (2) 241-252.

LESKE T and BUCKLEY C (2004b) Towards the development of a salinity impact category for South African life cycle assessments: Part 3 - Salinity potentials. Water SA 30 (2) 253-264.

NEITZEL H (1996) Principles of product-related life cycle assessment - Conceptual framework/Memorandum of understanding. Int. J. Life Cycle Assess. 1 (1) 49-54.

OWENS WJ (1999) Why life cycle assessment is now described as an indicator system. Int. J. Life Cycle Assess. 4 (2) 81-86.

RALUY RG, SERRA L, UCHE J and VALERO A (2005) Life Cycle Assessment of Water Production Technologies - Part 2: Reverse Osmosis Desalination versus the Ebro River Water Transfer. Int. J. Life Cycle Assessment online first < DOI: http://dx.doi.org/10.1065/ lca2004.09.179.2>

RAND WATER (2004) Rand Water Website: http://www.randwater. co.za/, accessed on 6 December 2005 .

RAYNOLDS M, FRASER R and CHECKEL D (2000a) The relative mass-energy-economic (RMEE) method for system boundary selection. Part 1: A means to systematically and quantitatively select LCA boundaries. Int. J. Life Cycle Assess. 5 (1) 37-48.

RAYNOLDS M, FRASER R and CHECKEL D (2000b) The Relative Mass-Energy-Economic (RMEE) method for system boundary selection. Part 2: Selecting the boundary cut-off parameter (ZRMEE) and its relationship to overall uncertainty. Int. J. Life Cycle Assess. 5 (2) 96-104.

ROSS S, EVANS D and WEBBER M (2002) How LCA studies deal with uncertainty. Int. J. Life Cycle Assess. 7 (1) 47-52.

SABS (SOUTH AFRICAN BUREAU OF STANDARDS) (1998) Code of Practice: Environmental Management - Life Cycle Assessment - Principles and Framework. SABS ISO 14040: 1997, Pretoria.

SABS (SOUTH AFRICAN BUREAU OF STANDARDS) (1999) Code of Practice: Environmental Management - Life Cycle Assessment - Goal and Scope Definition and Inventory Analysis. SABS ISO 14041: 1998, Pretoria.

TIBOR T and FELDMAN I (1996) ISO 14000 - A Guide to the New Environmental Management Standards. Irwin, Chicago.

VENTER I (2004) Seven tenants settle in at new Gauteng auto hub. Eng. News 24 (13) 18. 